\title{
Effect of the amino chain length and the transformation into citric acid salts of aryl- diphenyl-butenes and ferrocenyl-diphenyl- butenes bearing two dimethylaminoalkyl chains on their antimicrobial activities
}

\author{
Karim Jellali ${ }^{1 \dagger}$, Pascal Pigeon ${ }^{2}$, Fatma Trigui ${ }^{1}$, Siden Top ${ }^{2}$, Sami Aifa ${ }^{1}$, Gérard Jaouen ${ }^{2}$ and Mehdi El Arbi ${ }^{1,2^{*}+}$
}

\begin{abstract}
In a previous work we have demonstrated the antimicrobial activity of ferrocenyl or phenyl derivatives of diphenyl butene series. This finding has opened a new area of applications of organometallic compounds.

In order to improve these activities, we have synthesized new organic and organometallic diaryl butene compounds with different lengths of their amino chains. These new compounds, and also their ammonium salts, were tested against man pathogenic microorganisms Escherichia coli (ATCC 10536), Pseudomonas aeruginosa (ATCC 15442), Staphylococcus aureus (ATCC 6538) and Enterococcus hirae (ATCC 10541).

It emerged from the tests that the Gram+ bacteria are more sensitive to the compounds than Gram-, and the compounds with 3 carbon amino chains have a better antimicrobial activity than the one having a chain of 2 or 4 carbons.

The transformation of compounds to citrate salts was accompanied by a significant regression of antibacterial activity against Pseudomonas aeruginosa, for both organic and ferrocenic molecules. This resistance problem has been solved using hydrochlorides salts rather than citrates one.
\end{abstract}

Keywords: Diaryl butene; Antimicrobial activity; Citrate formulation; Citrate salts resistance; Hydrochlorides formulation

\section{Introduction}

According to global risk report published in 2013, antibiotic-resistant infections kill every year 100,000 Americans, 80,000 Chinese and 25,000 Europeans (Spellberg et al. 2011; Howell 2013). In fact, infections cost 21 to 34 Bn US\$/year in USA and 1,5 Bn Euro/year in Europe.

The frequency of antibiotic resistance is profoundly different from one European country to another. Europe was subject of an antibiotherapy study (ICAAC), made

\footnotetext{
*Correspondence: mehdi_arbi@yahoo.fr

${ }^{\dagger}$ Equal contributors

${ }^{1}$ Centre de Biotechnologie de Sfax (Université de Sfax), Route de Sidi Mansour Km 6, BP 1177, 3018 Sfax, Tunisia

${ }^{2}$ Chimie ParisTech (Ecole Nationale Supérieure de Chimie de Paris), Laboratoire Charles Friedel, UMR CNRS 7223, 11 rue Pierre et Marie Curie, 75231 Paris Cedex 05, France
}

by the team of Prof Voss, presented in 1992 to the U.S. Congress and published few years later (Voss et al. 1994). This study showed considerable differences in resistance rates of Staphylococcus aureus to meticillin (MRSA) between European countries, with rates ranging from $0 \%$ in some northern countries (Finland, Denmark, Sweden) to $35 \%$ and $40 \%$ in some countries that are more "Latin" (Italy, France). In some countries, MRSA studies, (Voss et al. 1994; Goldstein and Acar 1995) show that almost all strains were resistant to other antibiotics, especially quinolones and rifampicin. Resistance of Staphylococcus aureus to meticillin increased also in the most medically-advanced countries, even in United States of America (Gaynes et al. 1993). Every year MRSA kills 19,000 USA patients (more than emphysema, HIV/ AIDS, Parkinson's disease, and homicide combined).

\section{穴}


Recently a report titled «Global Risks 2013 », published by World economic forum, demonstrates a decrease on the rate of MRSA infections from 2008 to 2011 in the UK, Germany, Belgium, France and Spain to reach a rate included between $10 \%$ and $25 \%$, this rate increased in Hungary and Slovakia (25\% to < 50\%). In Portugal and Romania MRSA infections statistics are the highest with a rate up to $50 \%$. In addition, the increase of resistance rates for Gram negative bacilli such as Klebsiella pneumoniae in all Europe has been reported. This germ shows resistance to three classes of antibiotics combination (3rd generation cephalo-sporins, fluoroquinolones and aminoglycosides) with rates included between $1 \%$ and up to $50 \%$. A resistance that can be explained by production of $\beta$-lactamase with extended spectrum (Sirot et al. 1993; Burwin et al. 1994). Some countries are also faced with epidemic phenomena associated with the two species of gram-negative willingly multiresistant bacilli Acinetobacter baumannii and Stenotrophomonas maltophilia (Lortholary et al. 1995).

In Spain and France, an increase of pneumococcal resistance to penicillin has been reported (Pallares et al. 1995). This increase is due to the appearance of resistant gram positive cocci like Pneumococci (Pallares et al. 1995) and Enterococci (Spellberg et al. 2011; Howell 2013).

Clinical resistance is a complex phenomenon and its manifestation is dependent on many factors, but hospitals are not the only places where bacterial resistance can be developed. The use of biocides in agriculture and antibiotics in animal husbandry are two causes that accentuate the problem.

Allergy is one of the unpredictable problems associated with antibiotics use. This hypersensitivity is a drug reaction that is usually related to either the dose or the pharmacological action of the drug (Solensky 2006; Volcheck 2004). It accounts for approximately 6-10\% of all adverse drug reactions and the classes of antibiotics that are most commonly associated with allergic reactions are penicillins, cephalosporins, sulfonamides and macrolides (Gruchalla 2003).

To overcome drug resistance and to find new types of drugs, researchers have been exploring the possibility of using transition metal complexes as drugs against diverse diseases (Jaouen 2006; Hillard and Jaouen 2011; Patra et al. 2012; Gasser and Metzler-Nolte 2012; Chavin and Biot 2010; Hartinguer et al. 2009; Omelas 2011).

Ferrocenyl or phenyl derivatives of diphenyl butene series, tamoxifen analogues, known for their antitumor activity (Jaouen et al. 2000), showed also an excellent antimicrobial activity against Escherichia coli, Pseudomonas aeruginosa, Staphylococcus aureus and Enterococcus hirae (El Arbi et al. 2011). This finding, supported by published results of an American team regarding the efficacy of tamoxifen against Candida albicans (Dolan et al. 2009), opens a new area of applications to this type of compounds.

Bacterial resistance problems, the inefficiency of antibiotics discovered many years ago, the dual role of antibiotics in combating infectious and cancer diseases and the problem of allergy are good reasons to expend more efforts on the discovery of new active molecules.

On the same vision, this work has as objectives the synthesis of various diphenyl butene compounds with two amino chains, the exploration of the most effective structure microbiologically and the best appropriate formulation to make it water-soluble.

\section{Materials and methods}

\section{Synthesis and characterization of compounds}

The synthesis of all compounds was performed under an argon atmosphere, using standard Schlenk techniques. Anhydrous THF (tetrahydrofurane) was obtained by distillation from sodium/benzophenone. Thin layer chromatography was performed on silica gel 60 GF254. Infrared spectra were obtained on FT/IR-4100 JASCO spectrometers (http://www.jascofrance.fr). ${ }^{1} \mathrm{H}$ and ${ }^{13} \mathrm{C}$ NMR spectra were recorded on a $300 \mathrm{MHz}$ Bruker spectrometer (http://www.bruker.com). Mass spectrometry was performed with a Nermag R 10-10C spectrometer. Elemental analyses were performed by the microanalysis service of CNRS at Gif - sur - Yvette (https://www. imagif.cnrs.fr). The preparative HPLC (high performance liquid chromatography) separations were performed on a Shimadzu apparatus (http://www.shimadzu.fr) with a Nucleodur C18 column (length of $25 \mathrm{~cm}$, diameter of $2.5 \mathrm{~cm}$, and particle size of $10 \mu \mathrm{m})$.

\section{1-[Bis(4-hydroxyphenyl)methylidenyl]indan 10}

Titanium chloride (15.177 g, $8.79 \mathrm{~mL}, 80 \mathrm{mmoles}$ ) was added dropwise to a suspension of zinc powder (7.844 g, 120 mmoles $)$ in dry THF $(200 \mathrm{~mL})$ at $0-20^{\circ} \mathrm{C}$. The mixture was heated at reflux for 2 hours. A second solution was prepared by dissolving 1-indanone (2.643 g, $20 \mathrm{mmoles}$ ) and 4,4'-dihydroxybenzophenone (4.284 $\mathrm{g}$, 20 mmoles $)$ in dry THF $(50 \mathrm{~mL})$. This latter solution was added dropwise and the reflux was continued overnight. After cooling, the mixture was poured in water and dichloromethane was added. The mixture was acidified with diluted hydrochloric acid until dark color disappeared and was decanted. The aqueous layer was extracted with dichloromethane and the combination of organic layers was dried over magnesium sulphate. After concentration under reduced pressure, the crude product was chromatographed on silica gel column with a mixture of cyclohexane and ethyle acetate 50/50 as the eluent to give $\mathbf{1 0}$ as a white solid with a $79 \%$ yield. The 
characteristics of the product were identical to that of the literature (Kim and Katzenellenbogen 2000).

\section{1-[Bis(4-\{3-dimethylaminopropoxy\}phenyl)methylidenyl] indan 4}

Compound 10 (1.886 g, 6mmol), potassium carbonate ( $8.29 \mathrm{~g}, 60 \mathrm{mmol})$ and cesium carbonate $(3.91 \mathrm{~g}, 12 \mathrm{mmol})$ were stirred in $120 \mathrm{~mL}$ of acetone, then 3-dimethylamino1-propyl chloride hydrochloride (5.69 g, $36 \mathrm{mmol}$ ) was added. The mixture was refluxed overnight, cooled and concentrated under reduced pressure. The residue was extracted with a mixture of dichloromethane and water, then was decanted. The organic layer was washed twice with a diluted aqueous solution of sodium hydroxide followed with water, dried over magnesium sulphate then was concentrated under reduced pressure. The mixture was purified by HPLC using a $10 \%$ trietylamine solution in methanol to give 4 as oil with a $67 \%$ yield.

${ }^{1} \mathrm{H} \mathrm{NMR}\left(\mathrm{CDCl}_{3}\right): \delta$ 1.87-2.06 (m, $\left.4 \mathrm{H}, \mathrm{CH}_{2}\right), 2.27$ (s, $6 \mathrm{H}, \mathrm{NMe}_{2}$ ), 2.28 (s, $6 \mathrm{H}, \mathrm{NMe}_{2}$ ), 2.41-2.55 (m, $4 \mathrm{H}$, $\mathrm{CH}_{2} \mathrm{~N}$ ), 2.93 (s, $4 \mathrm{H}, \mathrm{H}_{\text {indane }}$ ), 3.95-4.09 (m, $\left.4 \mathrm{H}, \mathrm{CH}_{2} \mathrm{O}\right)$, $6.50\left(\mathrm{~d}, \mathrm{~J}=7.7 \mathrm{~Hz}, 1 \mathrm{H}, \mathrm{H}_{\text {arom }}\right), 6.78-6.92(\mathrm{~m}, 5 \mathrm{H}$, $\left.\mathrm{H}_{\text {arom }}\right), 7.01-7.25$ (m, $\left.6 \mathrm{H}, \mathrm{H}_{\text {arom }}\right) .{ }^{13} \mathrm{C} \mathrm{NMR}\left(\mathrm{CDCl}_{3}\right): \delta$ $27.9\left(2 \mathrm{CH}_{2}\right), 31.6\left(\mathrm{CH}_{2}\right.$ indane $), 34.8\left(\mathrm{CH}_{2}\right.$ indane $), 45.8$ $\left(2 \mathrm{NMe}_{2}\right), 56.7\left(\mathrm{CH}_{2} \mathrm{~N}\right), 56.8\left(\mathrm{CH}_{2} \mathrm{~N}\right), 66.5\left(2 \mathrm{CH}_{2} \mathrm{O}\right)$, $114.1\left(2 \mathrm{CH} \mathrm{C}_{6} \mathrm{H}_{4}\right), 114.9\left(2 \mathrm{CH} \mathrm{C}_{6} \mathrm{H}_{4}\right), 125.2\left(\mathrm{CH}_{\text {indane }}\right)$, $125.3\left(\mathrm{CH}_{\text {indane }}\right), 125.9\left(\mathrm{CH}_{\text {indane }}\right), 127.3\left(\mathrm{CH}_{\text {indane }}\right)$, $130.7\left(2 \mathrm{CH} \mathrm{C}_{6} \mathrm{H}_{4}\right), 131.4\left(2 \mathrm{CH} \mathrm{C}_{6} \mathrm{H}_{4}\right), 134.6(\mathrm{C}), 135.6$ (C), 136.7 (C), 139.6 (C), 142.0 (C), 147.9 (C), 157.9 (C), 158.4 (C). IR (KBr, $\left.v \mathrm{~cm}^{-1}\right)$ : 3063, 3033, 2940, 2854, 2813, $2763\left(\mathrm{CH}_{2}, \mathrm{CH}_{3}\right)$. MS (EI, $\left.70 \mathrm{eV}\right) \mathrm{m} / \mathrm{z}: 484[\mathrm{M}]^{+}$, $439,86\left[\mathrm{CH}_{2} \mathrm{CH}_{2} \mathrm{CH}_{2} \mathrm{NMe}_{2}\right]^{+}, 58\left[\mathrm{CH}_{2} \mathrm{NMe}_{2}\right]^{+}$.

\section{(1,1-bis-[4-(3-Dimethylamoniumpropoxy)phenyl]-2- ferrocenyl-but-1-ene dichloride 9)}

Diamino compound 5 (2.2 g, $3.7 \mathrm{mmol})$ was dissolved into $200 \mathrm{~mL}$ of diethyl ether. A $2 \mathrm{M}$ solution of hydrochloric acid in diethyl ether $(3.7 \mathrm{~mL}, 7.4 \mathrm{mmol}$ ) was added dropwise into the solution. An orange precipitate was immediately formed. After stirring for 20 min, the mixture was filtered under argon and the obtained orange solid was washed with $3 \times 5 \mathrm{~mL}$ of diethyl ether and was dried under vacuum giving compound 9 in 59\% yield. Crystals contain traces of diethyl ether.

${ }^{1} \mathrm{H}$ NMR (DMSO-d $\left.\mathrm{d}_{6}\right): \delta 1.02\left(\mathrm{t}, \mathrm{J}=7.4 \mathrm{~Hz}, 3 \mathrm{H}, \mathrm{CH}_{3}\right)$, 2.04-2.27 (m, $4 \mathrm{H}, 2 \mathrm{CH}_{2}$ ), 2.44-2.63 (m, $\left.2 \mathrm{H}, \mathrm{CH}_{2}\right), 2.79$ (s, $12 \mathrm{H}, \mathrm{NMe}_{2} \mathrm{H}^{+}$), 3.10-3.30 (m, $\left.4 \mathrm{H}, \mathrm{CH}_{2} \mathrm{~N}\right), 3.85$ (s, 2 $\left.\mathrm{H}, \mathrm{C}_{5} \mathrm{H}_{4}\right)$, 3.97-4.25 (m, $\left.11 \mathrm{H}, \mathrm{C}_{5} \mathrm{H}_{4}+\mathrm{C}_{5} \mathrm{H}_{5}+\mathrm{CH}_{2} \mathrm{O}\right)$, $6.86\left(\mathrm{~d}, \mathrm{~J}=8.0 \mathrm{~Hz}, 2 \mathrm{H}, \mathrm{C}_{6} \mathrm{H}_{4}\right), 6.90-7.01(\mathrm{~m}, 4 \mathrm{H}$, $\left.\mathrm{C}_{6} \mathrm{H}_{4}\right), 7.14\left(\mathrm{~d}, \mathrm{~J}=8.0 \mathrm{~Hz}, 2 \mathrm{H}, \mathrm{C}_{6} \mathrm{H}_{4}\right) .{ }^{13} \mathrm{C} \mathrm{NMR}$ $($ DMSO-d 6$): \delta 16.3\left(\mathrm{CH}_{3}\right), 24.8\left(2 \mathrm{CH}_{2}\right), 28.1\left(\mathrm{CH}_{2}\right)$, $42.9\left(2 \mathrm{NMe}_{2} \mathrm{H}+\right), 54.9\left(2 \mathrm{CH}_{2} \mathrm{~N}\right), 65.6\left(\mathrm{CH}_{2} \mathrm{O}\right), 65.8$ $\left(\mathrm{CH}_{2} \mathrm{O}\right), 68.8\left(2 \mathrm{CH} \mathrm{C} \mathrm{C}_{4}\right), 69.6\left(2 \mathrm{CH} \mathrm{C}_{5} \mathrm{H}_{4}\right), 69.9$
(5 $\left.\mathrm{CH} \mathrm{C}_{5} \mathrm{H}_{5}\right), 86.8\left(\mathrm{C} \mathrm{C}_{5} \mathrm{H}_{4}\right), 115.1\left(2 \times 2 \mathrm{CH} \mathrm{C}_{6} \mathrm{H}_{4}\right)$, $130.8\left(2 \mathrm{CH} \mathrm{C}_{6} \mathrm{H}_{4}\right), 131.3\left(2 \mathrm{CH} \mathrm{C}_{6} \mathrm{H}_{4}\right), 137.1(\mathrm{C}), 137.4$ (C), 137.9 (C), 138.2 (C), 157.5 (2 C) IR (KBr, v cm $\left.{ }^{-1}\right)$ : $3425(\mathrm{NH}), 3029,2960,2685,2510,2470\left(\mathrm{CH}_{2}, \mathrm{CH}_{3}\right)$.

\section{Microbial strains}

Known and newly synthesized compounds were tested against Escherichia coli (ATCC 10536), Pseudomonas aeruginosa (ATCC 15442), Staphylococcus aureus (ATCC 6538) and Enterococcus hirae (ATCC 10541).

All strains were cultured in liquid LB (1\% Bactotryptone, $0.5 \%$ Yeast extract, $0.5 \% \mathrm{NaCl}$ ).

\section{Estimation of the antimicrobial effect}

The estimation of the antimicrobial effect against microbial strains was performed by the method of microdilution in ELISA plates. A $2.5410^{-3} \mathrm{M}$ stock solutions of the tested products were prepared in DMSO or water, depending on their solubility. In Elisa plates and for each product a series of eight wells containing $100 \mu \mathrm{l}$ of culture medium with decreasing concentration of the product were prepared by the successive $1 / 2$ dilution.

A $100 \mu \mathrm{l}$ of overnight shaking microbial culture, incubated at adequate temperature, depending on bacterial strains, were used to inoculate the plate wells containing different concentrations of compounds. The final concentration of each product, for a series of eight wells was $2.5410^{-4} \mathrm{M}, 1.2710^{-4} \mathrm{M}, 6.3510^{-5} \mathrm{M}, 3.1810^{-5} \mathrm{M}$, $1.5910^{-5} \mathrm{M}, 7.9410^{-6} \mathrm{M}, 3.9710^{-6} \mathrm{M}$ and $1.9810^{-6} \mathrm{M}$. The plates were incubated with shaking overnight at the same temperature, depending on bacterial strains, and their OD was measured at $620 \mathrm{~nm}$.

A negative control (uninoculated wells), a positive control (seeded and without antimicrobial compound wells) were prepared under the same experimental conditions.

The inhibitory activity of the tested compounds was calculated according to the formula:

$$
\operatorname{IA}(\%)=100-100(\text { OD } 620(x) / O D \quad 620(\mathrm{i}))
$$

where $(x)$ is the microbial culture containing the inhibitor and (i) is the microbial culture without inhibitor.

\section{Results}

All compounds studied in the present work are shown in Figure 1.

\section{Synthesis}

The synthesis of compounds 1 (Shiina et al. 2008), 2 (Pigeon et al. 2011), 5 (Pigeon et al. 2011), and 8 (El Arbi et al. 2011), has already been published. Compounds 3, 6 and 7 are newly-synthesised products and their synthesis will be published in the future. 

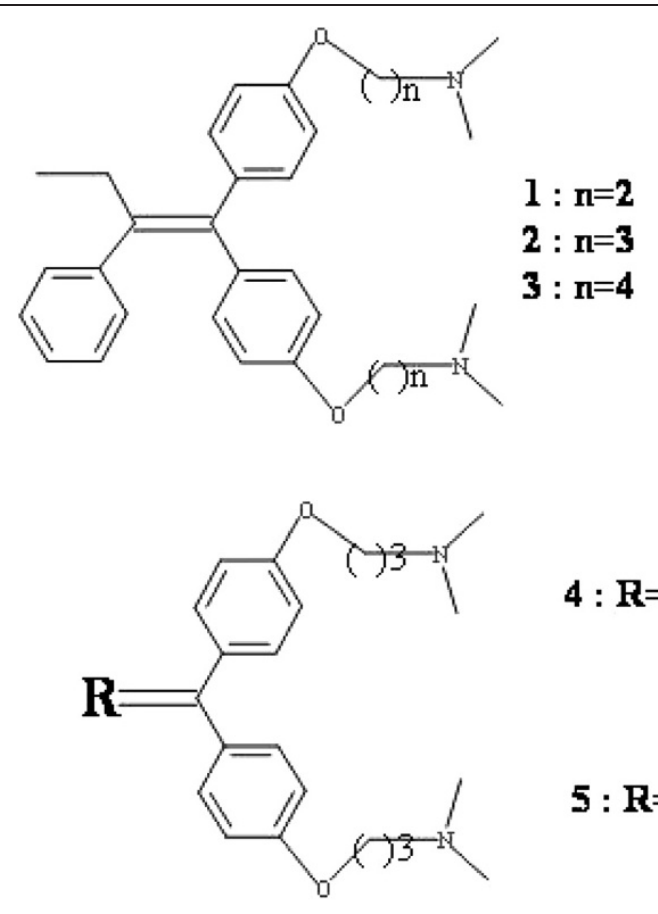

$4: \mathbf{R}=$
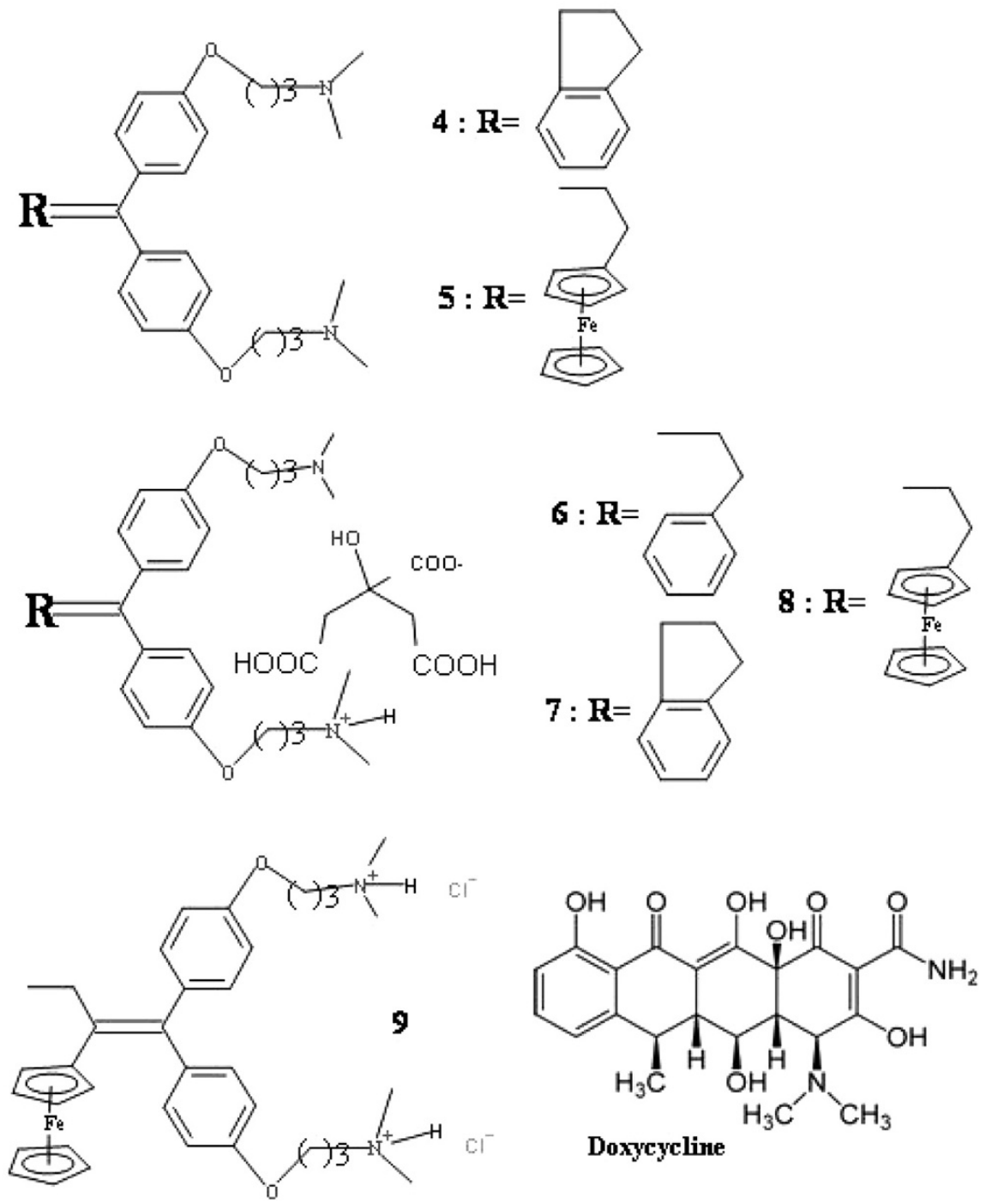

Figure 1 Chemicals tested.

Figure 2 shows the synthetic pathways of 4 . 10 was first prepared by reacting 1-indanone with 4,4'-dihydroxybenzophenone in the McMurry coupling conditions. This compound was converted into the diamine compound 4 by heating at reflux 3-dimethylamino-1-propyl chloride hydrochloride with $\mathbf{1 0}$ in acetone in the presence of potassium carbonate and cesium carbonate as bases. 4 was obtained in the yield of $67 \%$.

Hydrochloride 9 was prepared by adding 2 equivalents of hydrochloric acid to diamine compound $\mathbf{5}$ dissolved in diethyl ether (Figure 3). 9 was obtained in the yield of $59 \%$. 


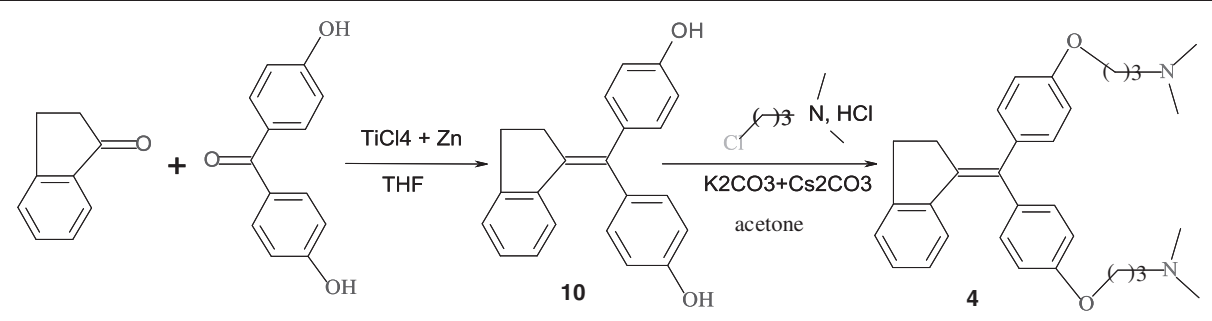

Figure 2 Synthesis of compounds 4 and 10.

\section{Effect of amino chain length on antimicrobial activity}

To evaluate the impact of the amino chain length on the antibacterial activity, organic compounds 1, 2 and 3, having an amino chain of 2,3 and 4 carbons, respectively, were selected for the test with four bacteria. At a concentration of $2.5410^{-4} \mathrm{M}$, as shown on Figure 4, all tested strains were sensitive to the three compounds. This result confirms again the activity of compound $\mathbf{3}$ (El Arbi et al. 2011). The tested compounds are effective against Gram+ and Gram- strains, but not with the same efficiency. Gram+ bacteria, Staphylococcus aureus and Enterococcus hirae, seem to be more sensitive than Gram- strains, Escherichia coli and Pseudomonas aeruginosa. Therefore, there is a potential use against Gram+ bacterial infections for these compounds. Within these compounds, the ones with 3 and 4 carbons are more potent comparing to the one of 2 carbons. It is interesting to note that these molecules increase the proliferation of micro-organisms when used at low doses.

\section{Effect of organic or organometallic compound on the antimicrobial activity}

It has been shown that ferrocenyl compounds are more active than their organic analogues against cancer cells (Top et al. 2003). It is interesting to see if this behavior is also verified for the antibacterial activity. Therefore, we compare now the activity of two organic compounds, the compounds $\mathbf{2}$ and $\mathbf{4}$, to that of ferrocenic compound 5. As shown in Figure 5, all compounds are more active against Gram + than Gram- bacteria. The difference in activity between organic and ferrocenic compounds is clearly observed in the case of Staphylococcus aureus. The inhibition percentage (IP) of $\mathbf{2}$ and $\mathbf{4}$ is about $94.32 \%$ at a dose of $3.5910^{-5} \mathrm{M}$ while that of $\mathbf{5}$ is 7.94 $10^{-6} \mathrm{M}$. In the case of Enterococcus hirae, the IP value of $59.21 \%$ is obtained using $7.9410^{-6} \mathrm{M}$ for both organic compounds and $1,9810^{-6} \mathrm{M}$ for organometallic compound. Therefore, the organometallic compound $\mathbf{5}$ is more potent, against Gram+ strains, than the organic compounds (4.5 times for Staphylococcus aureus and 4 times for Enterococcus hirae).

\section{Effect of the formulation of salts of citric acid on the antimicrobial activity}

Compounds 2, 4, 5 are not soluble in water. Their use as antimicrobial agents may be more convenient if they could be transformed into aqueous soluble forms. This transformation was achieved by their conversion into salts of citric acid. Thus, compounds $\mathbf{2}, \mathbf{4}$, and $\mathbf{5}$ were converted into compounds $\mathbf{6}, 7$, and $\mathbf{8}$, respectively. Figure 6 shows that the transformation of the compounds into salts did not alter their activity except for Pseudomonas aeruginosa. The activities against Staphylococcus aureus and Enterococcus hirae were maintained. We even observed an improvement of the antimicrobial activity effect against Escherichia coli, compound $\mathbf{6}$ expressed an IP of $96.2 \%$ at a dose of $6.3510^{-5} \mathrm{M}$ while 2 reaches this level of inhibition at a dose of $2.5410^{-4} \mathrm{M}$. By contrast, the loss of effectiveness against Pseudomonas aeruginosa was observed for all salts. Indeed, at the

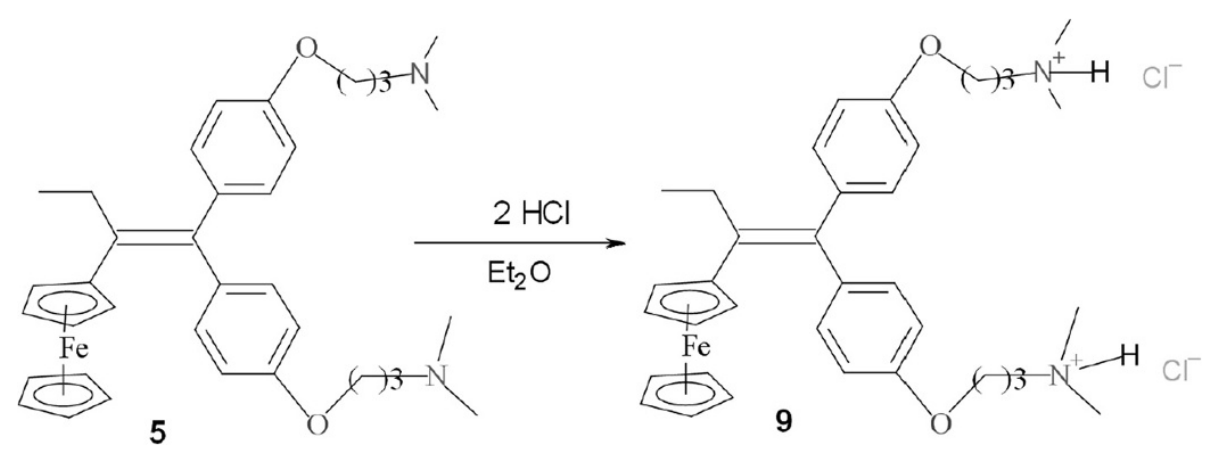

Figure 3 Synthesis of compound 9. 


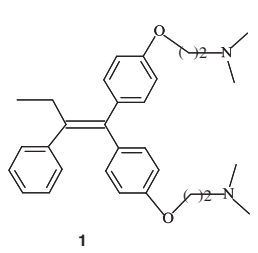

Staphylococcus aureus

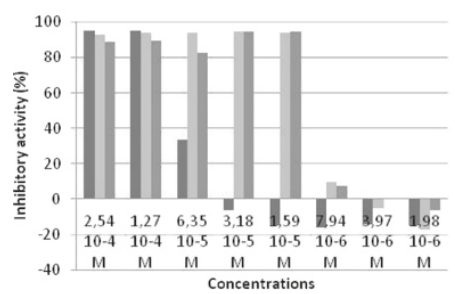

Escherichia coli

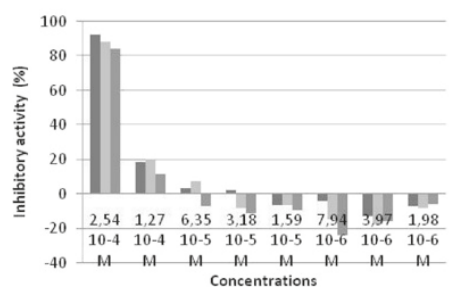

Figure 4 Antimicrobial activity of compounds 1, 2 and 3.
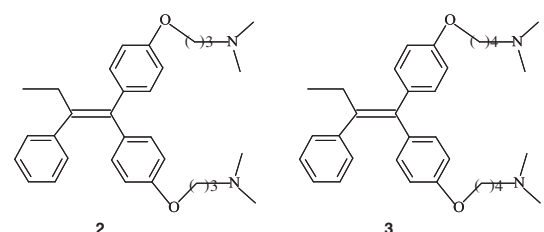

Pseudomonas aeruginosa

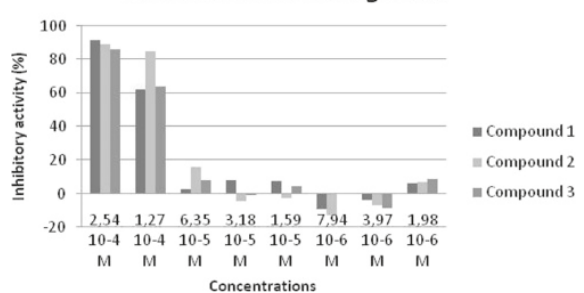

Enterococcus hirae

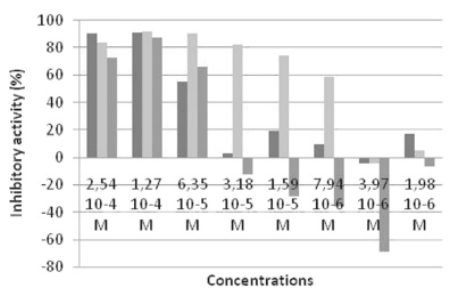

- Compound 1

$=$ Compound 2

m Compound 3

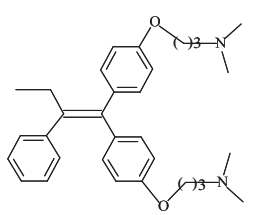

Staphylococcus aureus

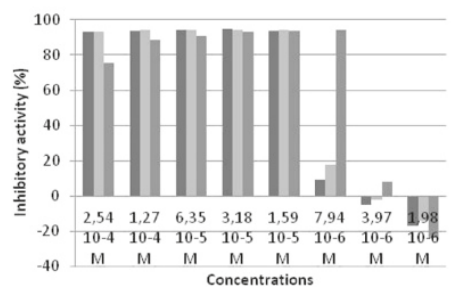

Escherichia coli

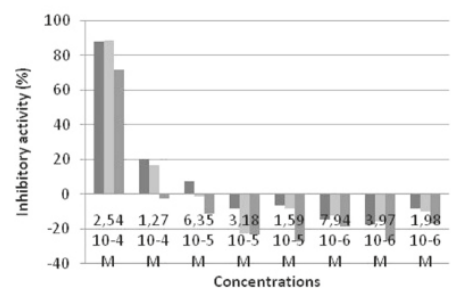

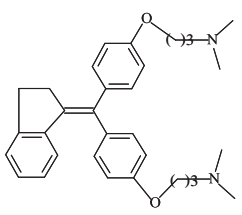

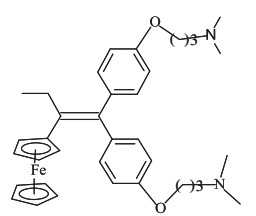

Pseudomonas aeruginosa
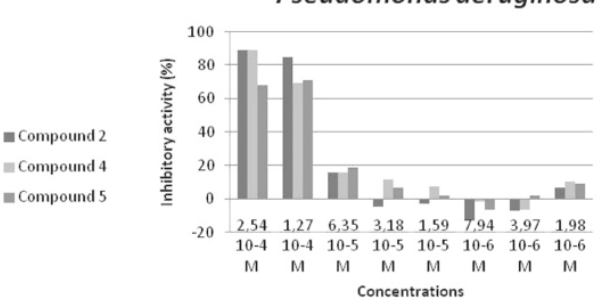

n Compound 2

$=$ Compound 4

$=$ Compound 5

Enterococcus hirae

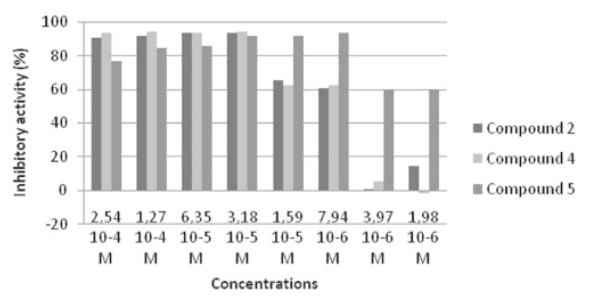

Figure 5 Antimicrobial activity of compounds 2, 4 and 5. 


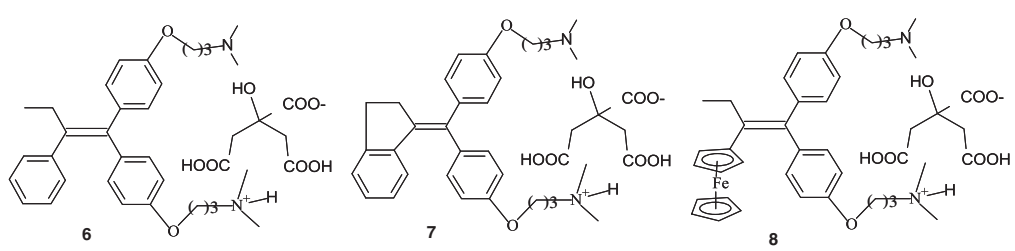

Staphylococcus aureus
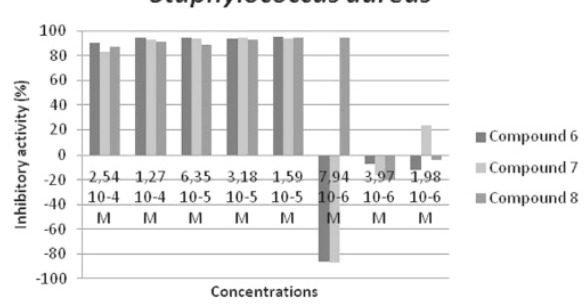

Pseudomonas aeruginosa

Escherichia coli

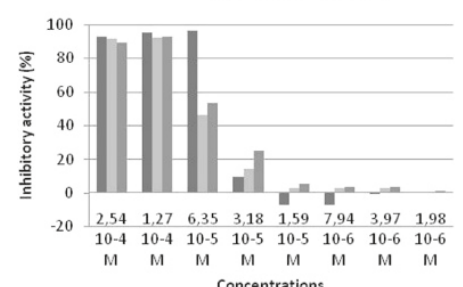

- Compound 6

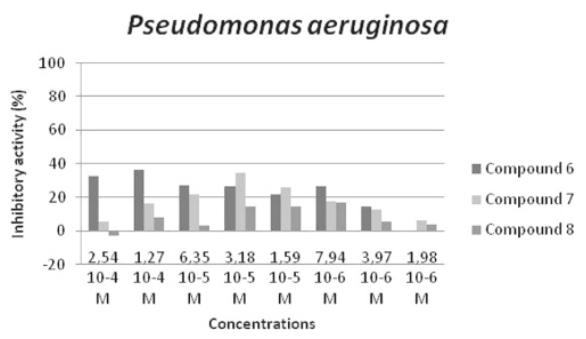

Figure 6 Antimicrobial activity of compounds 6, 7 and 8 .
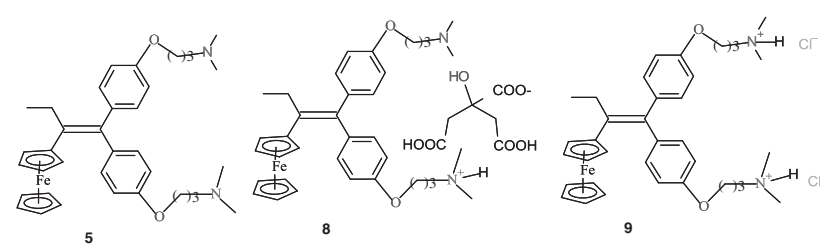

Staphylococcus aureus

Pseudomonas aeruginosa

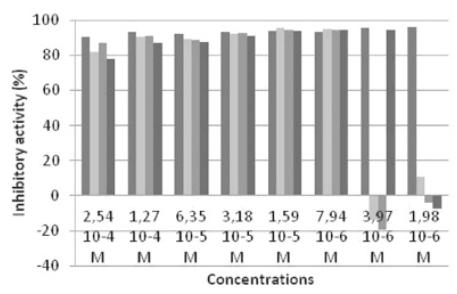

Doxycycline

- Compound 9

$=$ Compound 8

ncompound 5
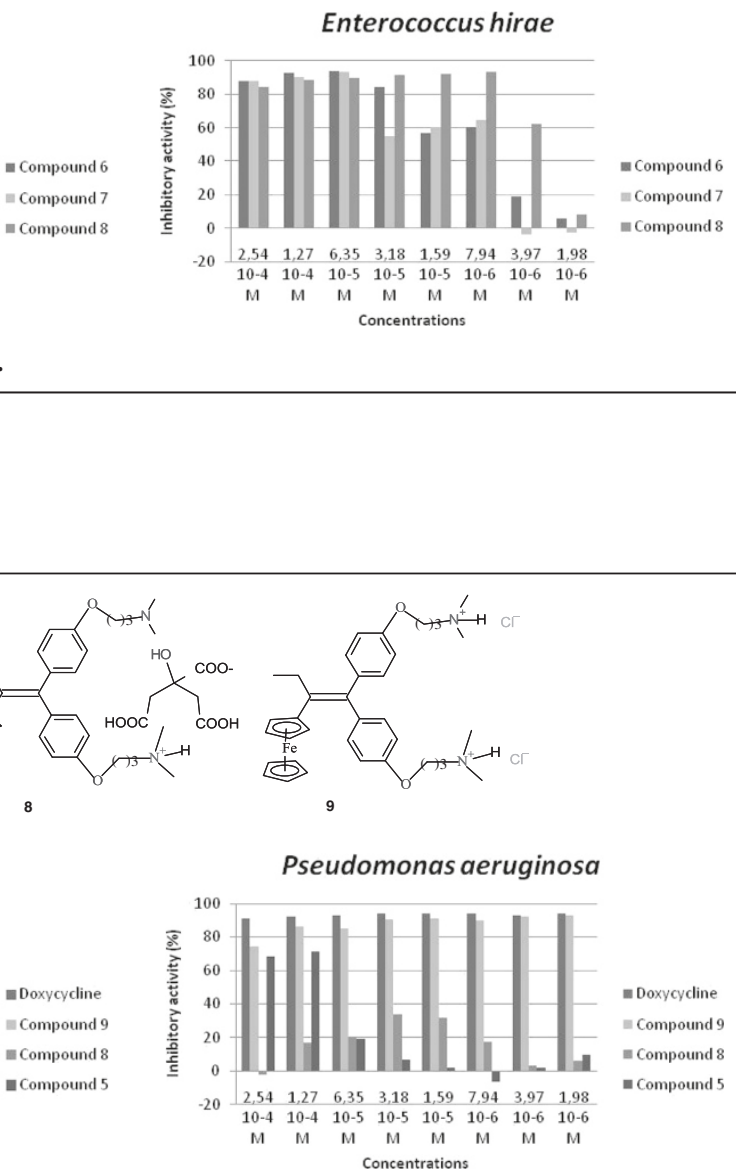

Escherichia coli

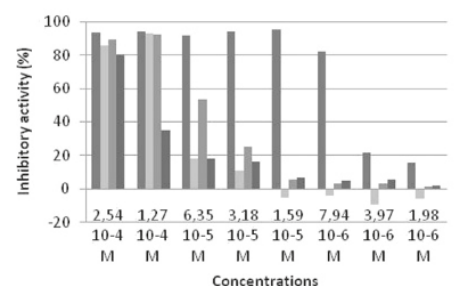

- Doxycycline

= Compound 9

= Compound 8

- Compound 5

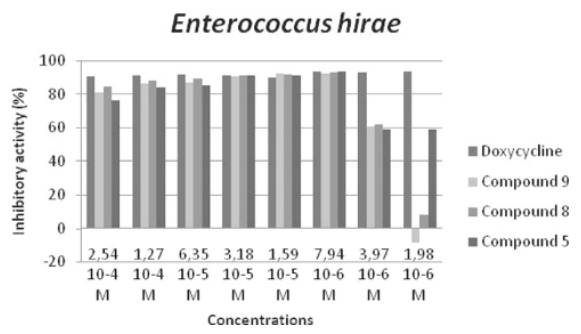

Figure 7 Antimicrobial activity of compounds 5, 8, 9 and Doxycycline. 
highest dose tested $\left(2.5410^{-4} \mathrm{M}\right)$, the inhibitory activity decreased from $89 \%, 89.46 \%$ and $63.38 \%$ for $\mathbf{2}, \mathbf{4}$ and $\mathbf{5}$, to $32.7 \%, 5.6 \%$ and $-2.7 \%$ for $\mathbf{6}, 7$, and $\mathbf{8}$, respectively.

\section{Effect of the transformation to hydrochloride on the antimicrobial activity}

The loss of activity of the salts against Pseudomonas aeruginosa prompted us to look for other salts forms of compounds. Thus, compound $\mathbf{5}$ was converted into hydrochloric salt 9. Figure 7 shows that 9 preserved both solubility in water and the compound $\mathbf{5}$ activity observed against Staphylococcus aureus, Enterococcus hirae and Escherichia coli. Interestingly, the loss of activity observed against Pseudomonas aeruginosa following the conversion of compound $\mathbf{5}$ into $\mathbf{8}$ was recovered by the compound $\mathbf{9}$.

Comparing to Doxycycline, an antibiotic of reference, 9 shows a similar activity and has an excellent antibacterial activity, especially against Gram+ (Figure 7).

\section{Discussion}

The present study confirms the importance of using tamoxifen and tamoxifen analogues in microbial inhibition. We found that tamoxifen and ferrocifen derivatives bearing two amino chains are active against bacteria. The activity of compounds can be improved by varying the length of the amino chain, the replacement of one of the arene rings of tamoxifen by a ferrocenyl unit, and by transforming the compounds into aqueous soluble forms. Thus, compounds with 3 carbon amino chain are more active than compounds with 2 and 4 carbon chains. Ferrocene derivatives, the ferrocifen series, have better activity than pure organic compounds (the tamoxifen series). Moreover, transforming the compounds into ammonium salts make the compounds soluble in water and improve the activity of compounds. For this last purpose, hydrochloric salts should be used rather than the citrate ones because of the resistance of Pseudomonas aeruginosa of this last salt form.

In addition to its antitumor efficacy, tamoxifen possession of antimicrobial properties has been recently reported (Dolan et al. 2009); meanwhile, knowing that tamoxifen is marketed as tamoxifen citrate, we want to warn following the results the possible ineffectiveness against Pseudomonas aeruginosa and the risk of aggravation of nosocomial infections, caused among others, by Pseudomonas aeruginosa.

We conclude that it is imperative to avoid the citrate salt formulation for antimicrobial products, because of the loss of compound activity against Pseudomonas aeruginosa. We also recommend trying other types of formulation for anti-tumor compounds, especially in the case of chemotherapy treatment, where citrate is used in low doses, which can offer an advantage of proliferative effect for microorganisms and biofilm formation (Robert et al. 2006).

\section{Competing interests}

We declare that we have no competing financial interests.

\section{Authors' contributions}

The French team, PP, ST and GJ, is responsible for the synthesis of compounds and the Tunisian team, KJ, FT, SA and ME is responsible for microbiological testing. In the same context, all authors contributed to the drafting and revision of the article and all have read and approved the final version.

\section{Acknowledgements}

This work was supported by the Ministry of Higher Education and Scientific Research of Tunisia and the "Agence Nationale de la Recherche" (France).

Received: 3 August 2013 Accepted: 27 September 2013

Published: 4 October 2013

\section{References}

Burwin D, Banerjee S, Gaynes R (1994) Ceftazidime resistance among selected nosocomial gram negative bacilli in United States. J Infect Dis 170:1622-1625

Chavain N, Biot C (2010) Organometallic complexes: new tools for chemotherapy. Curr Med Chem 17(25):2729-45

Dolan K, Montgomery S, Buchheit B, DiDone L, Wellington M, Krysan DJ (2009) Antifungal activity of tamoxifen: in vitro and in vivo activities and mechanistic characterization. Antimicrob Agents Chemother 53:3337-3346

El Arbi M, Pigeon P, Top S, Rhouma A, Aifa S, Rebai A, Vessières A, Plamont MA, Jaouen $G$ (2011) Evaluation of bactericidal and fungicidal activity of ferrocenyl or phenyl derivatives in the diphenyl butene series. J Organomet Chem 696:1038-1048

Gasser G, Metzler-Nolte N (2012) The potential of organometallic complexes in medicinal chemistry. Curr Opin Chem Biol 16:84-91

Gaynes R, Culver D, Horan T et al (1993) Trends in meticillin-resistant Staphylococcus aureus in United States hospitals. Infect Dis Clin Practice 2:452-455

Goldstein F, Acar J (1995) Epidemiology of quinolone resistance: Europe and North and South America. Drugs 49(2):36-42

Gruchalla RS (2003) Drug allergy. J Allergy Clin Immunol 111(suppl 2):S548-59

Hartinger CG, Dyson PJ (2009) Bioorganometallic chemistry : from teaching paradigms to medicinal applications. Chem Soc Rev 38:391-401

Hillard EA, Jaouen G (2011) Bioorganometallics: future trends in drug discovery, analytical chemistry and catalysis. Organometallics 30:20-27

Howell L (2013) Global risks: «The dangers of hubris on human health». World Economic Forum 8:28-35

Jaouen G (ed) (2006) Bioorganometallics: Biomolecules, Labeling, Medicine. Wiley-VCH Verlag GmbH \& Co, Weinheim, Germany

Jaouen G, Top S, Vessières A, Leclercq G, Quivy J, Jin L, Croisy A (2000) The first organometallic antioestrogens and their antiproliferative effects. Comptes Rendus de I'Académie des Sciences - Series IIC - . Chemistry 3:89-93

Kim S, Katzenellenbogen JA (2000) Triarylethylene bisphenols with a novel cycle are ligands for the estrogen receptor. Bioorg Med Chem 8:785-793

Lortholary O, Fagon JY, Buu Hoi A, Slama MA et al (1995) Nosocomial acquisition of multiresistant Acinetobacter baumanii : risk factors and prognosis. Clin Infect Dis 20:790-796

Omelas C (2011) Application of ferrocene and its derivatives in cancer research. New J Chem 35:1973-1985

Pallares R, Linares J, Vadillo M (1995) Resistance to penicillin and cephalosporin and mortality from severe pneumococcal pneumonia in Barcelona. Spain N Engl J Med 333:474-480

Patra M, Gasser G, Metzler-Nolte N (2012) Small organometallic compounds as antibacterial agents. Dalton Trans 41:6350-6358

Pigeon P, Top S, Vessières A, Huché M, Gormen M, El Arbi M, Plamont MA, McGlinchey MJ, Jaouen G (2011) A new series of ferrocifen derivatives, bearing two aminoalkyl chains, with strong antiproliferative effects on breast cancer cells. New J Chem 35(10):2212-2218

Robert MQ, Shanks JL, Sargent RMM, Martha LG, George AOT (2006) Catheter lock solutions influence staphylococcal biofilm formation on abiotic surfaces. Nephrol Dial Transplant 21:2247-2255

Shiina I, Sano Y, Nakata K, Kikuchi T, Sasaki A, Ikekita M, Nagahara Y, Hasome Y, Yamori T, Yamazaki K (2008) Synthesis and pharmacological evaluation of the novel pseudo-symmetrical tamoxifen derivatives as anti-tumor agents. Biochem Pharmacol 75:1014-1026 
Sirot D, Goldstein F, Soussy C (1993) Resistance to cefotaxime and seven other lactams in members of the family enterobacteriaceae: a three years survey in France. Antimicrob Agents Chemother 36:1667-1681

Solensky R (2006) Drug hypersensitivity. Med Clin N Am 90:233-60

Spellberg B, Blaser M, Guidos RJ et al (2011) Combating antimicrobial resistance: policy recommendations to save lives. Clin Infect Dis 52:S397-428

Top S, Vessières A, Leclercq G, Quivy J, Tang J, Vaissermann J, Huché M, Jaouen G (2003) Synthesis, Biochemical Properties and Molecular Modelling Studies of Organometallic Specific Estrogen Receptor Modulators (SERMs), the Ferrocifens and Hydroxyferrocifens: Evidence for an Antiproliferative Effect of Hydroxyferrocifens on both Hormone-Dependent and HormoneIndependent Breast Cancer Cell Lines. Chem Eur I 9:5223-5236

Volcheck G (2004) Clinical evaluation and management of drug hypersensitivity. Immunol Allergy Clin N Am 24:357-71

Voss A, Milatovic D, Wallrauch-Schwartz C, Rosdahl V, Braveny I (1994) Meticillinresistant Staphylococcus aureus in Europe. Eur J Clin Microbiol Infect Dis 13:50-55

doi:10.1186/2193-1801-2-508

Cite this article as: Jellali et al:: Effect of the amino chain length and the transformation into citric acid salts of aryl-diphenyl-butenes and

ferrocenyl-diphenyl-butenes bearing two dimethylaminoalkyl chains on their antimicrobial activities. SpringerPlus 2013 2:508.

\section{Submit your manuscript to a SpringerOpen ${ }^{\circ}$ journal and benefit from:}

- Convenient online submission

- Rigorous peer review

- Immediate publication on acceptance

- Open access: articles freely available online

- High visibility within the field

- Retaining the copyright to your article

Submit your next manuscript at $\gg$ springeropen.com 